\title{
Alpha Amylase, Alpha Glucosidase Inhibition and Profiling of Volatile Compounds of Biologically Active Extracts from Momordica cymbalaria (Hook, Fenzl) Skin and Seeds
}

\author{
E. Abbirami ${ }^{1}$, L. Dinesh Kumar ${ }^{2}$, R. Guna ${ }^{3}$, N. Gayathri ${ }^{4}$ and T. Sivasudha ${ }^{5^{*}}$ \\ 1,2,3,4\&5 Associate Professor, Department of Environmental Biotechnology, \\ Bharathidasan University, Tiruchirappalli, Tamil Nadu, India \\ *Corresponding author \\ E-Mail: sudha@bdu.ac.in, sudacoli@yahoo.com
}

\begin{abstract}
Momordica cymbalaria (Hook, Fenzl) has been used in traditional medicine for diabetes in India. This study was designed to examine, total phenolic, total flavonoid contents and in vitro anti-oxidant activity by using seven different types of solvent extracts. The biologically active extracts, ethanol extract of fruit skin (EESK) and methanol extract of seed (MESE) were evaluated for in vitro anti-diabetic activity followed by detection of bioactive metabolites by GC-MS analysis. EESK and MESE exhibited $\mathrm{IC}_{50}$ values of $185.1 \mu \mathrm{g} / \mathrm{ml}$ against $\alpha-$ amylase and $224.4 \mu \mathrm{g} / \mathrm{ml}$ against $\alpha$ - glucosidase, respectively. GC-MS profiling of skin and seed portion of the vegetable revealed the presence of 40 compounds from EESK and 29 compounds from MESE. Thus, this study reveals that EESK and MESE exhibited in vitro anti-diabetic activity and GC-MC profiling confirms the presence of anti-diabetic phytocompounds such as L-Cysteine and cis- Vaccenic acid. Keywords: Momordica cymbalaria, Anti-Oxidant Activity, In Vitro Anti-Diabetic Activity, GC-MS
\end{abstract}

\section{INTRODUCTION}

Natural products have drawn the attention of the research community due to their enormous health benefits like antioxidant, anti-cancer, anti-inflammatory, anti-diabetic activities, very less side effects and economic feasibility compared to synthetic medications. Moreover, consumer demands on functional foods is on rise in the developed and developing nations driven by an insatiable desire to obtain nutritional support from antioxidants, functional fats and dietary fibers. This assistance can improve the health quality of cardiovascular, nervous, immune and reproductive systems of the human body. Fruits and vegetables are the unbeatable sources of bio-actives such as phenolic compounds, flavonoids, terpenoids, carotenoids, natural catalysts and phytosterols with outstanding medicinal values. Additionally, these compounds play a vital role in catalyzing the metabolic processes besides being environmentally safer. Changing life style patterns, unhealthy eating and harmful environmental sources could increase the free radicals, resulting in the disruption of lipid, protein, carbohydrates and nucleic acids [1]. Scavenging ability of the electron hungry molecules by antioxidants is believed to be a significant step in preventing the damage to biologically important macromolecules. Free radicals include mainly Reactive Oxygen Species (Superoxide radicals, hydroxyl radicals, hydrogen peroxides etc.) and Reactive Nitrogen Species (nitric oxide and peroxy nitrite), which play a critical part in the initiation and upsurge of various diseases such as diabetes, atherosclerosis, cardiovascular diseases, neurodegenerative diseases, cancer and premature aging [2].

To overcome the disease induction by the free radicals and to maintain the oxidative balance, living organisms have enzymatic and non-enzymatic antioxidants which help to scavenge the indigenously formed free radicals [3]. Meanwhile, plant based antioxidants have been reported to play important role in the inhibition of tumor growth, aging in brain and neuronal cells, retardation of neurodegenerative diseases like Alzheimer's and Parkinson's disease [4]. In addition to this, antioxidants possess a wide variety of applications such as food preservators [5] polymeric membranes [6]. The use of synthetic antioxidants in food preservation results in adverse effects. Those can be replaced by antioxidants from plant origin which are more compatible with mankind and not only considered as safe but also could be more effective than synthetic ones. In recent years, a lot of research works have been carried out in the context of identifying innocuous and potent natural anti-antioxidants.

Momordica cymbalaria (Hook, Fenzl) (MC) is a more prominent nutritious vegetable of South India. It is a perennial climber of Cucurbitacea family which is available only during the monsoon season, found in the Indian states of Andhra Pradesh, Karnataka, Madhya Pradesh, Maharashtra and Tamil Nadu. MC has been used as traditional medicine for diabetes mellitus and rheumatic disorders [7]. It is a close relative of bitter melon (Momordica charantia) which is better known for its antidiabetic activity and bitter in taste similar to bitter melon. Decreasing postprandial hyperglycemia by inhibition of carbohydrate hydrolyzing enzymes such as, $\alpha$-amylase and $\alpha$ - glucosidase is one of the therapeutic approaches [8]. Until now, acarbose and voglibose are used either alone or in combination with insulin [9] as an inhibitor of carbohydrate digestive enzymes. However, harmful effects of these compounds, such as liver disorders, flatulence, 
abdominal fullness and diarrhea, have been reported [10]. In such a context, the intention of this work are (i) the evaluation and comparison of the quality and quantity of phytochemicals, as well as the anti-oxidant properties, (ii) the investigation of the in vitro anti-diabetic property and metabolite profiles of the antioxidant rich extracts by GCMS and (iii) detection of the appropriate solvent which aids extraction of active ingredients from the skin and seeds of MC.

\section{MATERIALS AND METHODS}

\section{A. Reagents and M. cymbalaria Extracts Preparation}

All chemical products used in this study were of analytical grade. $\alpha$-amylase, $\alpha$-glucosidase, starch, acarbose, dinitrosalicilic acid (DNS), $p$-nitrophenyl- $\beta$-Dglucopyranoside (pNPG), 2,2-diphenyl-1-picrylhydrazyl (DPPH), 2,2'-azino-bis (3-ethylbenzothiazoline-6-sulphonic acid (ABTS) and butylated hydroxyl toluene (BHT), were purchased from Sigma-Aldrich Co. (St. Louis, USA). All the other chemicals used were of analytical grade. Fruits of $M$. cymbalaria were obtained from the local market Sivakasi, Tamil Nadu, India and taxonomically confirmed by the Department of Botany, St. Joseph's College Tiruchirappalli, Tamil Nadu, India (Specimen NumberSJCBOT2561). The skin and seed portions of the vegetable MC were separated lyophilized and ground to powder using electronic grinder. Powdered skin and seed samples of MC, weighing ten grams were extracted with polar and non-polar solvents such as hexane (HX), chloroform (CL), ethyl acetate (EA), ethanol (ET), hydro alcohol (HA), methanol (MT) and aqueous(AQ) respectively, with the help of soxhlet apparatus. After the extraction, solvent was evaporated under reduced pressure at $45^{\circ} \mathrm{C}$ by the rotary evaporator (Buchi R-210, Flawil, Switzerland) to obtain the crude extract powder and stored at $-20{ }^{\circ} \mathrm{C}$ until use.

\section{B. Quantification of Total Phenolic and Flavonoid Contents, In vitro antioxidant Assays}

The amount of total phenolics content was determined using Foline-Ciocalteu method [11]. Total flavonoids were estimated using the method of Ordonez et al. [12].The antioxidant capacity of $M$. cymbalaria skin and seed extracts to scavenge the free radicals was studied by the following in vitro antioxidants assays,2,2-diphenyl- 1picrylhydrazyl (DPPH) radical scavenging activity [13], 2,2'-azino-bis(3-ethylbenzothiazoline-6-sulphonic acid (ABTS) free radical scavenging activity [14], Nitric oxide radical scavenging activity [15] and reducing power activity [16].

\section{C. $\alpha$ - Glucosidase and $\alpha$ - Amylase Inhibitory Activities}

$\alpha$ - Glucosidase inhibitory activity was assayed according to the procedure described by Ademiluyi et al., [17] and Chipiti et al., [18] with a slight modification. The inhibition of $\alpha$-amylase is a modification of the method previously described by Adedayo et al., [17] and Shai et al., [19].

\section{Metabolite profiling by GC-MS}

A gas-chromatograph (GC 7890 A) coupled with a mass spectrometer (MS 5975 C with Triple-Axis Detector, Agilent Technologies, Santa Clara, CA, USA) was used to analyze the ethanolic skin and methanolic seed extracts derived from MC. Separation was performed on a capillary column, Agilent DB5MS $(30 \mathrm{~m} \times 0.25 \mathrm{~mm}$ internal diameter, $0.25 \mu \mathrm{m}$ film thickness). The operating conditions of the column were as follows: Initially, GC oven temperature was held at $50{ }^{\circ} \mathrm{C}$ for $1.3 \mathrm{~min}$ and then the temperature was gradually increased to $250{ }^{\circ} \mathrm{C}$ at the rate of $6{ }^{\circ} \mathrm{C} / \mathrm{min}$ and from $250{ }^{\circ} \mathrm{C}$ to $310{ }^{\circ} \mathrm{C}$ at the rate of $7{ }^{\circ} \mathrm{C} /$ min withhold time of $2 \mathrm{~min}$. Finally the temperature was increased to $325^{\circ} \mathrm{C}$ and held for $3 \mathrm{~min}$. Sample injection (1 $\mu \mathrm{l})$ was performed in splitless mode at $250{ }^{\circ} \mathrm{C}$. Helium was used as a carrier gas at a flow rate of $1 \mathrm{ml} / \mathrm{min}$. The massspectrometer detector was operated under electron multiplier voltage (EMV) mode. The MS temperatures adopted were source $230^{\circ} \mathrm{C}$, quadrupole $150^{\circ} \mathrm{C}$; the acquisition range $50-550 \mathrm{~m} / \mathrm{z}$. Identification of compounds was obtained by comparing the retention times with those of authentic compounds and the spectral data obtained from NIST (National Institute of Standards and Technology, US) library.

\section{E. Statistical analysis}

Statistical analysis was performed using SPSS software (Version 25). All results are expressed as mean \pm standard deviation. Means with different letters are significantly different from each other. Differences with $\mathrm{p}<0.05$ were considered statistically significant. Comparison of mean values was carried out by one-way ANOVA and Duncan's post-hoc test. All experiments were performed with at least performed with three replicates.

\section{RESULTS AND DISCUSSION}

\section{Total Phenolic and Flavonoid Contents}

The $M$. cymbalaria ethanol skin extract (EESK) showed the highest phenolics content $(37.81 \pm 0.36 \mathrm{mg}$ of GAE/g of dry weight of the extract) and flavonoids content $(21.13 \pm 0.55$ $\mathrm{mg}$ of RE/g of dry weight of the extract). Among the seed extracts, it was the methanol seed extract (MESE) that showed the highest phenolics content $(16.72 \pm 0.47 \mathrm{mg}$ of GAE/g of dry weight of the extract) and flavonoids content (17.5 $\pm 0.04 \mathrm{mg}$ of RE/g of dry weight of the extract). Both in the skin and seed extracts, the lowest TPC (skin $=6.24 \pm$ $0.50 \mathrm{mg}$ of $\mathrm{GAE} / \mathrm{g}$ of dry weight of the extract; seed $=5.57$ $\pm 0.31 \mathrm{mg}$ of $\mathrm{GAE} / \mathrm{g}$ of dry weight of the extract) was shown by the chloroform extract and the lowest TFC (skin = $11.46 \pm 0.32 \mathrm{mg}$ of RE/g of dry weight of the extract; seed = $11.66 \pm 0.47 \mathrm{mg}$ of RE/g of dry weight of the extract) was shown by hexane. The total phenolics content and total flavonoids content of the skin and seed extracts were given in Table I. 
Alpha Amylase, Alpha Glucosidase Inhibition and Profiling of Volatile Compounds of Biologically Active Extracts from Momordica cymbalaria (Hook, Fenzl) Skin and Seeds

TABLE I TOTAL PHENOLIC AND FLAVONOID CONTENTS OF M. CYMBALARIA SKIN AND SEED EXTRACTS

\begin{tabular}{|l|c|c|c|c|}
\hline \multirow{2}{*}{ Extracts } & \multicolumn{2}{|c|}{ Total Phenolic Content $(\mathbf{m g}$ of GAE/g) } & \multicolumn{2}{c|}{ Total Flavonoid Content $(\mathbf{m g}$ of RE/g) } \\
\cline { 2 - 5 } & Skin & Seed & Skin & Seed \\
\hline Hexane & $8.63 \pm 0.32^{\mathrm{e}}$ & $10.69 \pm 0.31^{\mathrm{d}}$ & $11.46 \pm 0.32^{\mathrm{f}}$ & $11.66 \pm 0.47^{\mathrm{e}}$ \\
\hline Chloroform & $6.24 \pm 0.50^{\mathrm{f}}$ & $5.57 \pm 0.31^{\mathrm{d}}$ & $17.53 \pm 0.32^{\mathrm{b}}$ & $12.10 \pm 0.43^{\mathrm{d}, \mathrm{e}}$ \\
\hline Ethyl acetate & $17.33 \pm 0.29^{\mathrm{d}}$ & $6.09 \pm 0.27^{\mathrm{e}}$ & $14.36 \pm 0.41^{\mathrm{d}}$ & $13.83 \pm 0.47^{\mathrm{b}, \mathrm{c}}$ \\
\hline Ethanol & $37.81 \pm 0.36^{\mathrm{a}}$ & $16.66 \pm 0.22^{\mathrm{a}}$ & $21.13 \pm 0.55^{\mathrm{a}}$ & $14.53 \pm 0.40^{\mathrm{b}}$ \\
\hline Hydroalochol & $23.90 \pm 0.18^{\mathrm{b}}$ & $15.15 \pm 0.31^{\mathrm{b}}$ & $15.9 \pm 0.78^{\mathrm{c}}$ & $11.90 \pm 0.20^{\mathrm{e}}$ \\
\hline Methanol & $17.45 \pm 0.63^{\mathrm{d}}$ & $16.72 \pm 0.47^{\mathrm{a}}$ & $17.73 \pm 0.40^{\mathrm{b}}$ & $17.5 \pm 0.04^{\mathrm{a}}$ \\
\hline Aqueous & $20.45 \pm 0.18^{\mathrm{c}}$ & $12.51 \pm 0.54^{\mathrm{c}}$ & $12.93 \pm 0.45^{\mathrm{e}}$ & $13.03 \pm 1.25^{\mathrm{c}, \mathrm{d}}$ \\
\hline
\end{tabular}

GAE - Gallic Acid Equivalents; RE - Rutin Equivalents. Values are expressed as mean \pm standard deviation $(\mathrm{n}=3)$.

The mean values followed by different superscripts within the column are significantly different $(\mathrm{p}<0.05)$.

\section{In vitro Antioxidant Activity}

The kinetic behaviors of scavenging of DPPH radical for various solvent extracts of skin and seed of M. cymbalaria are shown in Fig.1 (a) and Fig.1 (b). The ethanol extract showed the inhibition of DPPH radicals with $\mathrm{IC}_{50}$ value of $102.23 \mu \mathrm{g} / \mathrm{ml}$ among the skin extracts of MC. On the other hand, MESE showed excellent inhibition with $\mathrm{IC}_{50}$ of $91.11 \mu \mathrm{g} / \mathrm{ml}$. ABTS assay is the widely accepted free radical scavenging method which is based on the hydrogen donating ability of antioxidant compounds. Both ethanol skin extract $\left(\mathrm{IC}_{50}=81.57 \mu \mathrm{g} / \mathrm{ml}\right)$ and methanol seed extract $\left(\mathrm{IC}_{50}=85.01 \mu \mathrm{g} / \mathrm{ml}\right)$ were equally good at scavenging ABTS radicals than the other solvent extracts [Fig.1(c) and Fig.1 (d)]. Graphs in Fig.1 (e) and Fig.1 (f) shows the nitric oxide scavenging activity of skin extracts of MC. The
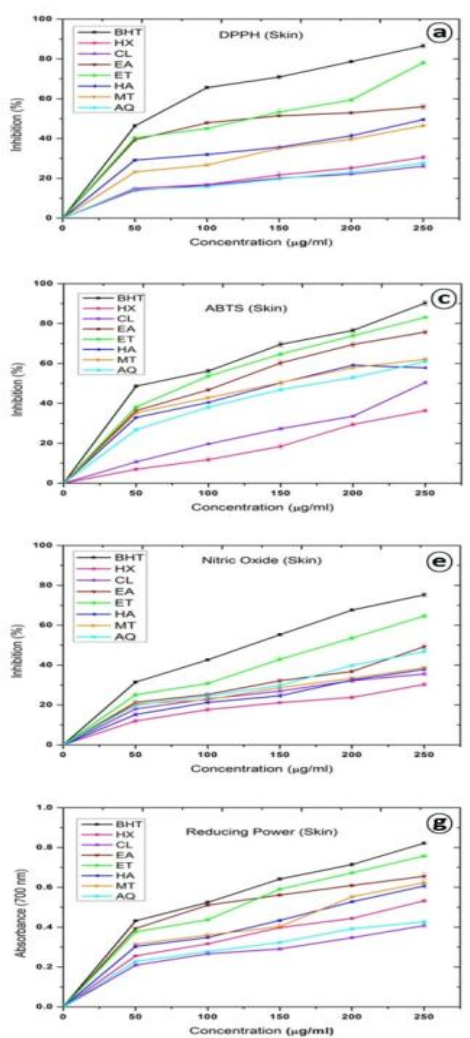

Fig. 1 In vitro anti-oxidant activities of Momordica cymbalaria (a) DPPH skin, (b) DPPH seed, (c) ABTS skin, (d) ABTS seed, (e) Nitric oxide skin, (f)

Nitric oxide seed, (g) Reducing power skin, (h) Reducing power seed ethanol extract of skin once again gave the highest scavenging activity with $\mathrm{IC}_{50}$ of $173 \mu \mathrm{g} / \mathrm{ml}$ than that of the other extracts. Meanwhile, the methanol extract of seeds revealed the scavenging potential of nitric oxide radicals at, $\mathrm{IC}_{50}$ of $194.5 \mu \mathrm{g} / \mathrm{ml}$. The reducing activity was determined based on the ability of skin and seed extracts to reduce a ferricyanide complex to form ferrous complex Fig.1 (g) and Fig.1 (h). The amount of $\mathrm{Fe}^{2+}$ reduced was monitored by measuring the formation of perl'sprussian blue at $700 \mathrm{~nm}$. The reducing power of the $M$. cymbalaria was observed to increase with increasing concentration of extracts. The highest reducing activity was recorded by BHT $(0.8213 \pm$ 0.00 at $250 \mu \mathrm{g} / \mathrm{ml}$ ) whereas out of 14 skin and seed extracts, ethanol skin extract $(0.7573 \pm 0.00$ at $\mu \mathrm{g} / \mathrm{ml})$ and methanol seed extract $(0.7373 \pm 0.00$ at $\mu \mathrm{g} / \mathrm{ml})$ have exhibited better reducing activity [20].
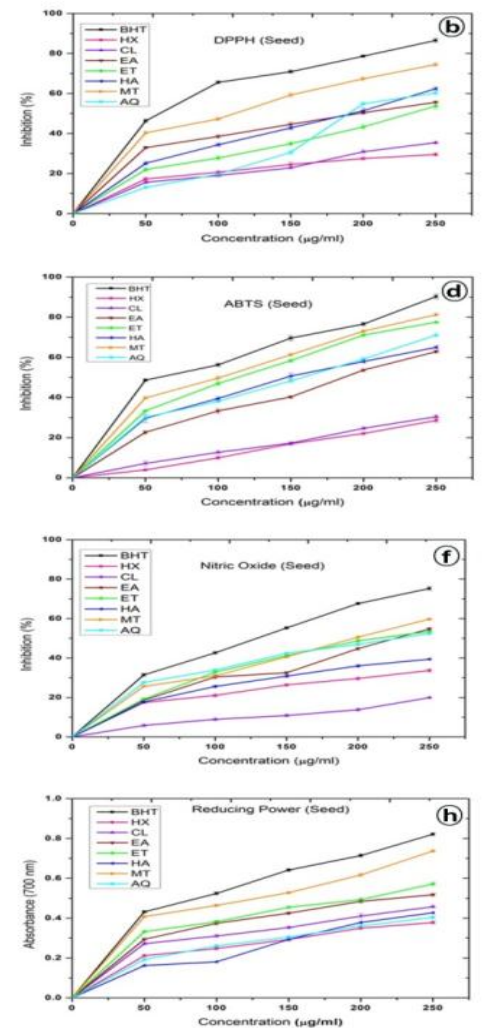


\section{In vitro Anti-Diabetic Activity and GC-MS Profiling}

As the ethanolic extract of skin (EESK) and methanolic extract of seed (MESE) revealed higher quantity of total phenolics and flavonoids content, those extracts were chosen to investigate the in vitro anti-diabetic activity and metabolite profile by GC-MS. Alpha glucosidase and alpha amylase inhibitors have become a new treatment strategy to combat diabetes mellitus [21]. It has been observed that, the MESE showed $50 \%$ of alpha glucosidase inhibition at a concentration of $224.4 \mu \mathrm{g} / \mathrm{ml}$ which was lower than the EESK $(245.9 \mu \mathrm{g} / \mathrm{ml})$ and higher than the standard compound acarbose which showed 50\% inhibition at 104.3 $\mu \mathrm{g} / \mathrm{ml}$. The inhibition percentages of alpha amylase enzyme by acarbose, EESK and MESE were presented in Table II. Conversely, in this assay against alpha amylase, EESK showed $50 \%$ inhibition at a concentration of $185.1 \mu \mathrm{g} / \mathrm{ml}$ which was much lesser than MESE $(231.0 \mu \mathrm{g} / \mathrm{ml})$. On the other hand, acarbose showed 50\% inhibition at a lower concentration of $79.79 \mu \mathrm{g} / \mathrm{ml}$.

TABLE II In Vitro ANTI-DiabETIC ACTIVITIES OF M. CYMBALARIA EXTRACTS

\begin{tabular}{|c|c|c|c|c|}
\hline $\begin{array}{l}\text { Samples } \\
(\mu \mathrm{g} / \mathrm{ml})\end{array}$ & \multicolumn{2}{|c|}{$\alpha$ - Glucosidase } & \multicolumn{2}{|c|}{$\alpha$ - Amylase } \\
\hline Acarbose & $\begin{array}{l}\text { Inhibition } \% \pm \\
\text { S.D }\end{array}$ & $\begin{array}{r}\mathrm{IC}_{50} \\
(\mathrm{~g} / \mathrm{ml})\end{array}$ & $\begin{array}{l}\text { Inhibition\% } \% \\
\text { S.D }\end{array}$ & $\begin{array}{r}\mathrm{IC}_{50} \\
(\mu \mathrm{g} / \mathrm{ml})\end{array}$ \\
\hline 50 & $29.38 \pm 1.13^{\mathrm{j}}$ & \multirow{5}{*}{104.3} & $34.86 \pm 1.39^{\mathrm{i}}$ & \multirow{5}{*}{79.79} \\
\hline 100 & $44.24 \pm 0.63^{g}$ & & $55.78 \pm 0.77^{\mathrm{e}}$ & \\
\hline 150 & $60.53 \pm 1.01^{\mathrm{c}}$ & & $70.97 \pm 1.10^{\mathrm{c}}$ & \\
\hline 200 & $72.96 \pm 1.26^{\mathrm{b}}$ & & $81.00 \pm 0.68^{b}$ & \\
\hline 250 & $82.61 \pm 1.15^{\mathrm{a}}$ & & $90.07 \pm 0.42^{\mathrm{a}}$ & \\
\hline \multicolumn{5}{|c|}{ EESK } \\
\hline 50 & $14.52 \pm 0.76^{\mathrm{n}}$ & \multirow{5}{*}{245.9} & $16.43 \pm 0.76^{\mathrm{m}}$ & \multirow{5}{*}{185.1} \\
\hline 100 & $26.19 \pm 0.50^{\mathrm{k}}$ & & $28.06 \pm 0.34^{\mathrm{k}}$ & \\
\hline 150 & $31.06 \pm 0.63^{\mathrm{i}}$ & & $40.36 \pm 0.42^{\mathrm{h}}$ & \\
\hline 200 & $45.17 \pm 0.14^{g}$ & & $51.13 \pm 0.76^{\mathrm{f}}$ & \\
\hline 250 & $51.88 \pm 0.75^{\mathrm{e}}$ & & $64.05 \pm 0.59^{\mathrm{d}}$ & \\
\hline \multicolumn{5}{|c|}{ MESE } \\
\hline 50 & $19.81 \pm 1.13^{\mathrm{m}}$ & \multirow{5}{*}{224.4} & $11.79 \pm 0.76^{\mathrm{n}}$ & \multirow{5}{*}{231} \\
\hline 100 & $23.92 \pm 0.90^{1}$ & & $23.35 \pm 0.80^{1}$ & \\
\hline 150 & $37.53 \pm 0.75^{\mathrm{h}}$ & & $32.76 \pm 0.68^{\mathrm{j}}$ & \\
\hline 200 & $47.85 \pm 0.75^{\mathrm{f}}$ & & $43.02 \pm 0.51^{g}$ & \\
\hline 250 & $54.49 \pm 0.38^{\mathrm{d}}$ & & $55.55 \pm 0.51^{\mathrm{e}}$ & \\
\hline
\end{tabular}

Values are expressed as mean \pm standard deviation $(n=3)$. The mean values followed by different superscripts within the column are significantly different $(\mathrm{p}<0.05) . \mathrm{IC}_{50}-$ quantity $(\mu \mathrm{g} / \mathrm{ml})$ of $\mathrm{MC}$ skin and seed extracts needed to inhibit $50 \%$ of the reactive species in the assay.

GC-MS analysis of EESK yielded 40 compounds whereas MESE yielded 29 compounds. The metabolites with their retention time (RT), molecular formula, molecular weight, peak area $\%$ are presented in Table III. The skin and seed extracts of MC showed that, it was mainly composed of 8 categories of compound: saturated fatty acids, unsaturated fatty acids, esters, hormones, aromatic compounds, amino acids, heterocyclic compounds and aliphatic compounds. Glycerin, hexadecanoic acid methyl ester, n- hexadecanoic acid, heptadecanoic acid, cis- vaccenic acid and octadecanoic acid were the six co-existing compounds found in the chromatograms of EESK and MESE (Table III).According to the GC-MS analysis of EESK [Fig. 2 (a)], the major peak (27) was observed at the retention time of 21.420 with $\mathrm{m} / \mathrm{z}, 73.00$ and the compound was identified as n- hexadecanoic acid.

Peak (35) was the second major peak which was identified asoctadecanoic acid at the retention time of 23.198 with $\mathrm{m} / \mathrm{z}$ 73.00. Peak 34 (9, 12, 15 -octadecatrienoic acid), peak 32 (phytol) and peak 21(bicyclo heptanes, 2, 6, 6-trimethyl 3octadecyne) were the other major peaks obtained at $\mathrm{m} / \mathrm{z}$ $79.10, \mathrm{~m} / \mathrm{z} 71.10$ and $\mathrm{m} / \mathrm{z} 68.10$. In the chromatogram of MESE [Fig.2 (b)], peak 23 was detected as the largest peak (Rt: 23.220) with $\mathrm{m} / \mathrm{z} 73.00$ and the compound was identified as octadecanoic acid. Cis -vaccenic acid was detected as the next largest peak with $\mathrm{m} / \mathrm{z} 55.10$ at retention time 23.017. Peaks 25 and 15, were the other major peaks, identified as methyl eleostearate and palmitic acid at $\mathrm{m} / \mathrm{z}$ 79.10 and $\mathrm{m} / \mathrm{z} 73.00$ respectively. It is interesting to highlight that, cis-vaccenic acid, an omega -7 fatty acid which was identified both in the skin and seed extracts, has been reported for graded associations with lower insulin resistance and risk of diabetes, in type 2 diabetic patients [22]. In addition to this, several studies demonstrates the importance of L-cysteine supplementation as an adjuvant therapy for type 2 diabetes mellitus [23] and enhancement of insulin sensitivity [24]. Therefore, these outcomes provide the biochemical exposition to incorporate EESK and MESE as part of dietary assistance for managing diabetes mellitus.

TABLE III Tentative IDENTIFICATION OF Volatile COMPOUNDS Through GC-Ms ANALYSIS

\begin{tabular}{|c|l|c|c|c|c|}
\hline \multicolumn{5}{|c|}{ Identification of phytochemicals in EESK of Momordica cymbalaria } \\
\hline Peak & \multicolumn{1}{|c|}{ Detected Metabolites } & $*$ RT(min) & $\begin{array}{c}\text { Molecular } \\
\text { Formula }\end{array}$ & $\begin{array}{c}\text { Molecular } \\
\text { Weight(g/mol) }\end{array}$ & Area \% \\
\hline 1 & N,N- Dimethyl- 2- aminoethanol & 6.859 & $\mathrm{C}_{4} \mathrm{H}_{11} \mathrm{NO}$ & 89.136 & 2.12 \\
\hline 2 & 3,4-Dimethyldihydrofuran-2,5-dione & 10.290 & $\mathrm{C}_{6} \mathrm{H}_{8} \mathrm{O}_{3}$ & 128.126 & 6.45 \\
\hline 3 & Glycerin & 11.003 & $\mathrm{C}_{3} \mathrm{H}_{8} \mathrm{O}_{3}$ & 92.094 & 10.43 \\
\hline 4 & 2,3- Furandione, dihydro-4,4-dimethyl & 11.207 & $\mathrm{C}_{6} \mathrm{H}_{8} \mathrm{O}_{3}$ & 128.13 & 0.80 \\
\hline
\end{tabular}


Alpha Amylase, Alpha Glucosidase Inhibition and Profiling of Volatile Compounds of Biologically Active Extracts from Momordica cymbalaria (Hook, Fenzl) Skin and Seeds

\begin{tabular}{|c|c|c|c|c|c|}
\hline 5 & 4N-Ethylcytosine & 13.528 & $\mathrm{C}_{6} \mathrm{H}_{9} \mathrm{~N}_{3} \mathrm{O}$ & 139.158 & 0.95 \\
\hline 6 & 2-Methoxy -4- vinylphenol & 14.592 & $\mathrm{C}_{9} \mathrm{H}_{10} \mathrm{O}_{2}$ & 150.177 & 0.46 \\
\hline 7 & $1,2,3,4-$ Butanetetrol & 15.000 & $\mathrm{C}_{4} \mathrm{H}_{10} \mathrm{O}_{4}$ & 122.12 & 2.51 \\
\hline 8 & DL-Proline, 5-oxo-, methyl ester & 15.374 & $\mathrm{C}_{6} \mathrm{H}_{9} \mathrm{NO}_{3}$ & 143.141 & 1.09 \\
\hline 9 & 1-Cyclohexene-1-carboxylic acid & 15.509 & $\mathrm{C}_{7} \mathrm{H}_{10} \mathrm{O}_{2}$ & 126.155 & 2.46 \\
\hline 10 & 2-Azetidinone & 15.928 & $\mathrm{C}_{3} \mathrm{H}_{5} \mathrm{NO}$ & 71.078 & 2.71 \\
\hline 11 & Cyclopropane, pentyl & 16.732 & $\mathrm{C}_{8} \mathrm{H}_{16}$ & 112.213 & 1.60 \\
\hline 12 & 1,4-Bis(2-hydroxyethyl) piperazine & 17.253 & $\mathrm{C}_{8} \mathrm{H}_{18} \mathrm{~N}_{2} \mathrm{O}_{2}$ & 174.24 & 0.72 \\
\hline 13 & Dodecanoic acid & 17.332 & $\mathrm{C}_{12} \mathrm{H}_{24} \mathrm{O}_{2}$ & 200.318 & 1.01 \\
\hline 14 & Adipicdihydroxamic acid monohydrate & 17.457 & $\mathrm{C}_{6} \mathrm{H}_{12} \mathrm{~N}_{2} \mathrm{O}_{4}$ & 176.171 & 0.48 \\
\hline 15 & 2- Nonen -1-ol, 2-Methyl- & 18.182 & $\mathrm{C}_{10} \mathrm{H}_{20} \mathrm{O}$ & 156.265 & 0.40 \\
\hline 16 & Butanoic acid, ethyl ester & 18.272 & $\mathrm{C}_{6} \mathrm{H}_{12} \mathrm{O}_{2}$ & 116.158 & 0.50 \\
\hline 17 & Cyclohex-2-enone & 18.442 & $\mathrm{C}_{6} \mathrm{H}_{8} \mathrm{O}$ & 96.1271 & 0.55 \\
\hline 18 & Tetradecanoic acid & 19.439 & $\mathrm{C}_{14} \mathrm{H}_{28} \mathrm{O}_{2}$ & 228.371 & 1.75 \\
\hline 19 & Cyclohexanone & 19.824 & $\mathrm{C}_{6} \mathrm{H}_{10} \mathrm{O}$ & 98.143 & 1.29 \\
\hline 20 & 1-Aza-7-oxa-bicycloheptan-6-one & 19.914 & $\mathrm{C}_{10} \mathrm{H}_{19} \mathrm{~N}$ & 153.265 & 0.88 \\
\hline 21 & Bicycloheptanes, 2,6,6-trimethyl 3-Octadecyne & 20.220 & $\mathrm{C}_{10} \mathrm{H}_{18}$ & 138.2499 & 2.32 \\
\hline 22 & 2- Pentadecanone, 6, 10, 14- trimethyl- & 20.276 & $\mathrm{C}_{18} \mathrm{H}_{36} \mathrm{O}$ & 268.478 & 1.66 \\
\hline 23 & Pentadecanoic acid & 20.435 & $\mathrm{C}_{15} \mathrm{H}_{30} \mathrm{O}_{2}$ & 242.398 & 1.09 \\
\hline 24 & 9-Octadecyne & 20.639 & $\mathrm{C}_{18} \mathrm{H}_{34}$ & 250.463 & 0.97 \\
\hline 25 & Hexadecanoic acid, methyl ester & 21.058 & $\mathrm{C}_{17} \mathrm{H}_{34} \mathrm{O}_{2}$ & 270.4507 & 0.75 \\
\hline 26 & $9-$ Hexadecenoic acid & 21.228 & $\mathrm{C}_{16} \mathrm{H}_{30} \mathrm{O}_{2}$ & 254.414 & 0.88 \\
\hline 27 & n- Hexadecanoic acid & 21.420 & $\mathrm{C}_{16} \mathrm{H}_{32} \mathrm{O}_{2}$ & 256.424 & 22.72 \\
\hline 28 & Hexadecanoic acid, ethyl ester & 21.681 & $\mathrm{C}_{18} \mathrm{H}_{36} \mathrm{O}_{2}$ & 284.477 & 2.02 \\
\hline 29 & 9 - Tricosene, (z)- & 22.179 & $\mathrm{C}_{23} \mathrm{H}_{45}$ & 322.621 & 0.50 \\
\hline 30 & Heptadecanoic acid & 22.303 & $\mathrm{C}_{17} \mathrm{H}_{34} \mathrm{O}_{2}$ & 270.451 & 0.64 \\
\hline 31 & cis- Vaccenic acid & 22.666 & $\mathrm{C}_{18} \mathrm{H}_{34} \mathrm{O}_{2}$ & 282.461 & 0.62 \\
\hline 32 & Phytol & 22.745 & $\mathrm{C}_{20} \mathrm{H}_{40} \mathrm{O}$ & 296.531 & 3.58 \\
\hline 33 & Methyl 16 -methyl- heptadecanoate & 22.858 & $\mathrm{C}_{19} \mathrm{H}_{38} \mathrm{O}_{2}$ & 298.504 & 0.42 \\
\hline 34 & 9,12,15- Octadecatrienoic acid & 23.017 & $\mathrm{C}_{18} \mathrm{H}_{30} \mathrm{O}_{2}$ & 278.436 & 8.86 \\
\hline 35 & Octadecanoic acid & 23.198 & $\mathrm{C}_{18} \mathrm{H}_{36} \mathrm{O}_{2}$ & 284.477 & 7.68 \\
\hline 36 & Octadecanoic acid, ethyl ester & 23.424 & $\mathrm{C}_{20} \mathrm{H}_{40} \mathrm{O}_{2}$ & 312.530 & 1.05 \\
\hline 37 & 9 - Tricosene $(\mathrm{Z})$ & 24.024 & $\mathrm{C}_{23} \mathrm{H}_{46}$ & 322.621 & 1.33 \\
\hline 38 & $\mathrm{~N}$-[Dimethylaminomethyl]aziridine & 24.194 & $\mathrm{C}_{5} \mathrm{H}_{12} \mathrm{~N}_{2}$ & 100.162 & 1.48 \\
\hline 39 & 1-Methyl-3-phenylindole & 24.545 & $\mathrm{C}_{15} \mathrm{H}_{13} \mathrm{~N}$ & 207.270 & 0.51 \\
\hline 40 & Pyridazine & 26.108 & $\mathrm{C}_{4} \mathrm{H}_{4} \mathrm{~N}_{2}$ & 80.09 & 1.75 \\
\hline \multicolumn{6}{|c|}{ Identification of phytochemicals in MESE of Momordica cymbalaria } \\
\hline Peak & Detected Metabolite & $* \mathbf{R T}(\mathbf{m i n})$ & $\begin{array}{l}\text { Molecular } \\
\text { Formula }\end{array}$ & $\begin{array}{c}\text { Molecular } \\
\text { Weight(g/mol) }\end{array}$ & Area \% \\
\hline 1 & Phenol & 10.052 & $\mathrm{C}_{6} \mathrm{H}_{6} \mathrm{O}$ & 94.111 & 1.39 \\
\hline 2 & Formic acid, butyl ester & 10.278 & $\mathrm{C}_{5} \mathrm{H}_{10} \mathrm{O}_{2}$ & 102.132 & 1.80 \\
\hline 3 & Glycerin & 10.912 & $\mathrm{C}_{3} \mathrm{H}_{8} \mathrm{O}_{3}$ & 92.094 & 11.78 \\
\hline 4 & Phenol, 2-methoxy- & 11.637 & $\mathrm{C}_{7} \mathrm{H}_{8} \mathrm{O}_{2}$ & 124.139 & 0.33 \\
\hline 5 & Azulene & 13.143 & $\mathrm{C}_{10} \mathrm{H}_{8}$ & 128.171 & 0.77 \\
\hline 6 & Cysteine & 13.437 & $\mathrm{C}_{6} \mathrm{H}_{12} \mathrm{~N}_{2} \mathrm{O}_{4} \mathrm{~S}_{2}$ & 240.292 & 0.41 \\
\hline 7 & N-Benzyl-2-aminocinnamate,methy & 13.879 & $\mathrm{C}_{17} \mathrm{H}_{17} \mathrm{NO}_{2}$ & 267.322 & 0.32 \\
\hline
\end{tabular}




\begin{tabular}{|c|c|c|c|c|c|}
\hline 8 & 2-Methoxy-4-vinylphenol & 14.592 & $\mathrm{C}_{9} \mathrm{H}_{10} \mathrm{O}_{2}$ & 150.174 & 0.22 \\
\hline 9 & Pyrrolidine, 2-butyl-1-methyl- & 15.351 & $\mathrm{C}_{18} \mathrm{H}_{37} \mathrm{~N}$ & 267.501 & 0.22 \\
\hline 10 & 1,3-Propanediamine, N-methyl- & 15.928 & $\mathrm{C}_{4} \mathrm{H}_{12} \mathrm{~N}_{2}$ & 88.15 & 0.12 \\
\hline 11 & 2-Tetradecene, $(\mathrm{E})$ - & 16.415 & $\mathrm{C}_{14} \mathrm{H}_{28}$ & 196.372 & 0.30 \\
\hline 12 & Tetraacetyl-d-xylonic nitrile & 19.450 & $\mathrm{C}_{14} \mathrm{H}_{17} \mathrm{NO}_{9}$ & 343.286 & 0.32 \\
\hline 13 & Hexadecanoic acid, methyl ester & 21.058 & $\mathrm{C}_{17} \mathrm{H}_{34} \mathrm{O}_{2}$ & 270.451 & 0.91 \\
\hline 14 & Adipamide & 21.239 & $\mathrm{C}_{6} \mathrm{H}_{12} \mathrm{~N}_{2} \mathrm{O}_{2}$ & 144.172 & 0.13 \\
\hline 15 & n-Hexadecanoic acid & 21.409 & $\mathrm{C}_{16} \mathrm{H}_{32} \mathrm{O}_{2}$ & 256.4241 & 10.86 \\
\hline 16 & Carbromal & 21.975 & $\mathrm{C}_{7} \mathrm{H}_{13} \mathrm{BrN}_{2} \mathrm{O}_{2}$ & 237.094 & 0.14 \\
\hline 17 & Propanamide & 22.065 & $\mathrm{C}_{3} \mathrm{H}_{7} \mathrm{NO}$ & 73.094 & 0.16 \\
\hline 18 & Heptadecanoic acid & 22.315 & $\mathrm{C}_{17} \mathrm{H}_{34} \mathrm{O}_{2}$ & 270.451 & 0.27 \\
\hline 19 & 9, 12-Octadecadienoic acid (Z,Z)-... & 22.609 & $\mathrm{C}_{19} \mathrm{H}_{34} \mathrm{O}_{2}$ & 294.472 & 1.02 \\
\hline 20 & 9-Octadecenoic acid (Z)-, methyl... & 22.654 & $\mathrm{C}_{19} \mathrm{H}_{36} \mathrm{O}_{2}$ & 296.488 & 1.64 \\
\hline 21 & Octadecanoic acid, methyl ester & 22.869 & $\mathrm{C}_{19} \mathrm{H}_{38} \mathrm{O}_{2}$ & 298.504 & 1.99 \\
\hline 22 & cis-Vaccenic acid & 23.017 & $\mathrm{C}_{18} \mathrm{H}_{34} \mathrm{O}_{2}$ & 282.461 & 17.36 \\
\hline 23 & Octadecanoic acid & 23.220 & $\mathrm{C}_{18} \mathrm{H}_{36} \mathrm{O}_{2}$ & 284.477 & 22.15 \\
\hline 24 & Methyl octadecatrienoate & 23.877 & $\mathrm{C}_{19} \mathrm{H}_{34} \mathrm{O}_{2}$ & 294.472 & 5.66 \\
\hline 25 & Methyl 9.cis., 11.trans.t,13.trans - octadecatrienoate & 24.206 & $\mathrm{C}_{18} \mathrm{H}_{30} \mathrm{O}_{2}$ & 278.430 & 13.00 \\
\hline 26 & Cyclopentanebutanoic acid methyl ester & 24.545 & $\mathrm{CC}_{10} \mathrm{H}_{18} \mathrm{O}_{2}$ & 170.249 & 3.55 \\
\hline 27 & Unknown compound & 25.485 & - & - & 2.07 \\
\hline 28 & $\begin{array}{l}\text { Ethanamine,2-[(4-chlorophenyl)-2-pyridinylmethoxy]-N,N- } \\
\text { dimethyl }\end{array}$ & 25.825 & $\mathrm{C}_{16} \mathrm{H}_{19} \mathrm{ClN}_{2 \mathrm{O}}$ & 290.78786 & 0.43 \\
\hline 29 & Sarcosine & 26.108 & $\mathrm{C}_{3} \mathrm{H}_{7} \mathrm{NO}_{2}$ & 89.094 & 0.66 \\
\hline
\end{tabular}

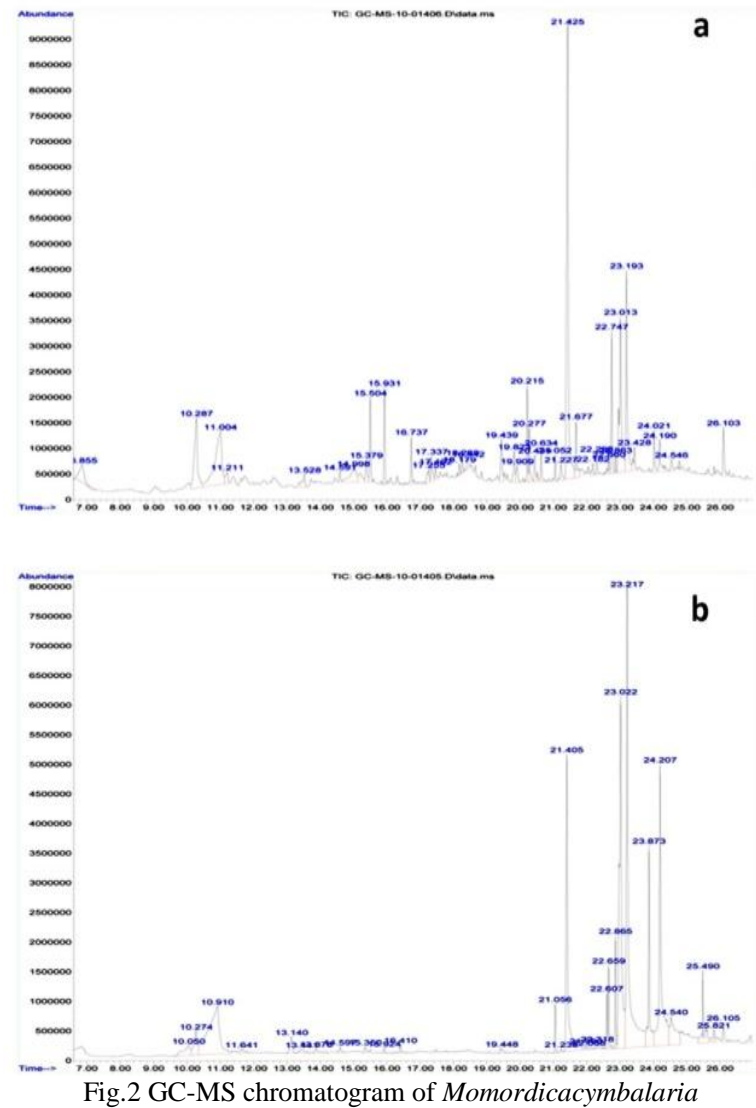

(a) EESK; (b) MESE

\section{CONCLUSION}

This study for the first time explored the in vitro antidiabetic effects of skin and seed extracts of Momordica cymbalaria. EESK and MESE showed high TPC, TFC, in vitro antioxidant activity, inhibition of alpha glucosidase and alpha amylase activity. On the whole, 69 compounds were identified in this vegetable via GC-MS analysis. Hence, both EESK and MESE can be considered as perfect source of natural antioxidants and anti-diabetic agents. Further studies can be directed towards the identification and structural elucidation of the bioactive compounds followed by animal studies and clinical trials to understand the anti-diabetic effects of $M$. cymbalaria.

\section{REFERENCES}

[1] O. M. Ighodaro and O. A. Akinloye, "First line defence antioxidantssuperoxide dismutase (SOD), Catalase (CAT) and glutathione peroxidase (GPX), Their fundamental role in the entire antioxidant defence grid", Alexandria Med J., Vol. 54, No.4, pp. 287-293, 2018.

[2] E. Stelmach, P. Pohl, and A. Szymczycha-Madeja, "The content of $\mathrm{Ca}, \mathrm{Cu}, \mathrm{Fe}, \mathrm{Mg}$ and $\mathrm{Mn}$ and antioxidant activity of green coffee brews", Food Chem.,182, pp. 302-308, 2015.

[3] Camilo Lopez-Alarcona and Ana Denicolab, "Evaluating the antioxidant capacity of natural products: A review on chemical and cellular-based assays", AnalyticaChimicaActa., Vol. 763, pp.1- 10, 2013.

[4] V. Sanguigni, M. Manco, R. Sorge, L. Gnessi, and D. Francomano, "Natural antioxidant ice cream acutely reduces oxidative stress and improves vascular function and physical performance in healthy individuals", Nutrition., Vol. 33, pp. 225-233, 2017. 
[5] MarcioCarochoa, Patricia Moralesb, and Isabel C.F.R. Ferreiraa., "Review Antioxidants: Reviewing the chemistry, food applications, legislation and role as preservatives", Trends FoodSci Tech., Vol.71, pp.107-120, 2018.

[6] S. Rajesh and Z. V. P. Murthy, "Synthesis, characterization and application of antioxidants nanoparticles incorporated polymeric membranes", Sep Sci Technol., pp. 1-11, 2018.

[7] R. Jeyadevi, T. Sivasudha, A. Rameshkumar, B. Sangeetha, D. Arul Ananth, and G. Smilin Bell Aseervatham, "Nutritional constituents and medicinal values of Momordicacymbalaria (Athalakkai) - A review", Asian Pac J Trop Biomed., pp. S456-S461, 2012.

[8] G. Oboh, A.O. Ademiluyi, A.J. Akinyemi, T.H. Henle, J.A. Saliu, and U. Schwarzenbolz, "Inhibitory effect of polyphenol rich extracts of jute leaf (Corchorusolitorius) on key enzyme linked to type 2 diabetes ( $\alpha$-amylase and $\alpha$-glucosidase) and hypertension(angiotensin I converting) in vitro", J Funct Foods., Vol. 4, pp. 450 - 458, 2012.

[9] M. Modak, P. Dixit, J. Londhe, S. Ghaskadbi, and T.P.A. Devasagayam, "Indian herbs and herbal drugs used for the treatment of diabetes", J ClinBiochemNutr., Vol. 40, pp. 163-173, 2007.

[10] T. Fujisawa, H. Ikegami, K. Inoue, Y. Kawabata, and T. Ogihara, "Effect of two alpha-glucosidase inhibitors, voglibose and acarbose, on postprandial hyperglycemia correlates with subjective abdominal symptoms", Metabolism., Vol. 54, pp. 387-390, 2002.

[11] V. L. Singleton, J. A. Rossi, "Colorimetry of total phenolics with phosphomolibdicephosphotungtic acid reagents", Am J EnolVitic., Vol. 16, pp. 144-158, 1965.

[12] A. A. L. Ordonez, J. D. Gomez, M. A. Vattuone, and M. I. Isla, "Antioxidant activities of sedule(Jacq.) Swart extracts", Food Chem., Vol. 97, pp. 452-58, 2006.

[13] C.M. Liyana-Pathiranan and F. Shahidi, "Antioxidant activity of commercial soft and hard wheat (Triticumaestivum L) as affected by gastric pH conditions", J Agric Food Chem., Vol. 53, pp. 2433-2440, 2005.

[14] R. Re, N. Pellegrini, A. Proteggente, A. Pannala, M. Yang and C. Rice-Evans, "Antioxidant activity applying an improved ABTS radical cationdecolorization assay", Free RadicBiol Med., Vol. 26, pp. 1231-37, 1999.
[15] D. C. Garrat, The quantitative analysis of drugs. $3^{\text {rd }}$ ed., Chapman and. Hall Ltd: Japan, Vol. 3, pp. 456-458, 1964

[16] M. Oyaizu, "Studies on products of browning reaction prepared from glucoseamine", Jap J Nutr., Vol. 44, pp. 307-14, 1986.

[17] A. O. Ademiluyi and G. Oboh, "Soybean phenolic-rich extracts inhibit key-enzymes linked to type 2 diabetes ( $\alpha$-amylase and $\alpha$ glucosidase) and hypertension (angiotensin I converting enzyme) in vitro", Exp Toxicol Pathol., Vol. 65, No. 3, pp. 305-9, 2013.

[18] T. Chipiti, M.A. Ibrahim, M. Singh, and M.S. Islam, "In vitro $\alpha$ amylase and $\alpha$-glucosidase inhibitory and cytotoxic activities of extracts from Cissuscornifolia planch parts" PharmacognMag., Vol. 13, pp. S329, 2017. -glucosi

[19] L. J. Shai, S.R. Magano, S.L. Labelo, and A.M. Mogale, "Inhibitory effects of five medicinal plants on rat alpha- glucosidase: Comparison with their effects on yeast alpha- glucosidase", J Med Plants Res., Vol. 5, No.13, pp.2836- 2867, 2011. amylase

[20] Z. Derakhshan, M. Ferrante, M. Tadi, F. Ansari, A. Heydari, M.S. Hosseini, G.O. Conti, and E.K. Sadrabad, "Antioxidant activity and total phenolic content of ethanolic extract of pomegranate peels, juice and seeds", Food Chem Toxicol., Vol. 114, pp. 108-111, 2018.

[21] S. Kumar, S. Narwal, V. Kumar, and O. Prakash, " $\alpha$-glucosidase inhibitors from plants: A natural approach to treat diabetes". Phcog Rev. Vol.5, No.9, pp.19-29, 2011.result tpc

[22] N. L. Weir, L. Johnson, W. Guan, B. Stefeen, L. Djousse, K.J. Mukamal, and M.Y. Tsai, "Cis-Vaccenic Acid Is Associated with Lower HOMA-IR and Incident T2D in Participants from the MESA Cohort", Diabetes., Vol. 67, No. 1, 2018.

[23] S. K. Jain, "L-cysteine supplementation as an adjuvant therapy for type-2 diabetes", Can. J. Physiol. Pharmacol. Vol. 90, No. 8, pp. 1061- 4, 2012.

[24] D. Nguyen, J. W. Hsu, F. Jahoor, and R. V. Sekhar, "Effect of increasing glutathione with cysteine and glycine supplementation on mitochondrial fuel oxidation, insulin sensitivity, and body composition in older HIV-infected patients", J. Clin. Endocrinol. Metab. Vol. 99 No. 1, pp. 169-77. 